\title{
Gendered Innovations in

\section{Gendered Innovations in Orthopaedic Science: From Access to Zygote: A Gender and Orthopaedics Lexicon}

\author{
Amy L. Ladd MD
}

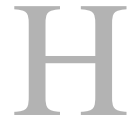
enry Kissinger once said, "Nobody will ever win the Battle of the Sexes. There is just too much fraternizing with the enemy." Words, on the other hand, can win battles or wage war. Harmful words, however unintentional, may

Note from the Editor-in-Chief:

We are pleased to present to readers of

Clinical Orthopaedics and Related

Research ${ }^{\mathbb{R}}$ the latest installment of

"Gendered Innovations in Orthopaedic

Science” by Amy L. Ladd MD. Dr. Ladd is a

Professor in the Department of Orthopaedics at Stanford University, and is the Past-

President of the Ruth Jackson Orthopaedics Society. She provides commentary on sex and gender similarities and differences in orthopaedics.

The author certifies that she, or any members of her immediate family, have no funding or commercial associations (eg, consultancies, stock ownership, equity interest, patent/ licensing arrangements, etc) that might pose a conflict of interest in connection with the submitted article.

All ICMJE Conflict of Interest Forms for authors and Clinical Orthopaedics and Related Research ${ }^{\circledR}$ editors and board members are on file with the publication and can be viewed on request.

The opinions expressed are those of the writers, and do not reflect the opinion or policy of Clinical Orthopaedics and Related Research $^{\circledR}$ or the Association of Bone and Joint Surgeons ${ }^{\circledR}$. dehumanize or bias research, including in musculoskeletal science [6]. Alternatively, words can educate, stimulate, and, at times, diffuse tense situations. Recall the dry-witted Spartans and their legacy of the laconic phrase. Philip II of Macedon threatened invasion upon the Ancient Greek city-state of Laconia, sending the message, "If I invade Laconia you will be destroyed, never to rise again." To this threat, the Laconians volleyed, "If." This word alone allegedly kept Sparta safe, lasting the reign of Philip and his son, Alexander the Great.

In the spirit of words that amuse, educate, and highlight, please find a lexicon to enhance your scrutiny of sex and gender issues in musculoskeletal science.

A - Access: When doors open, we reach new heights in the athletic and science arena. Witness two-time Nobel laureate Marie Curie, Title IX, and Little League World Series

A. L. Ladd MD (ه)

Chase Hand and Upper Limb Center, Stanford University, 770 Welch Rd., Suite 400, Palo Alto, CA 94304-1801, USA

e-mail: aladd@stanford.edu; alad@stanford.edu pitching star Mo'Ne Davis. Once women joined the engineering teams, crash test dummies started to include pregnant women and children [7]. Fortune 500 companies with women on their boards have higher return on equity, superior sales, and greater return on investment [9].

B - Bones: The heart of the musculoskeletal system. A bone is an organ unto itself. Bones make blood, permit a foundation to stand upright, define if we are a child or an adult, and solve most riddles of human evolution. Osteoporosis in men was poorly diagnosed until male bone density values were established.

C - Curriculum: Our musculoskeletal medical school curriculum is in great need of overhaul and implementation to meet the high demand of musculoskeletal injuries, disorders, and disease that affect nearly a majority of our US citizens [3, 4]. Underrepresented minorities and women with early exposure to science, technology, engineering, and mathematics (STEM) curricula enter these fields at higher rates, and succeed in them. Orthopaedic surgery is the logical extension of this: Early exposure to musculoskeletal education yields more 


\section{Gendered Innovations in Orthopaedic Science}

qualified and diverse orthopaedic surgeons $[3,10]$.

D - Dearth: A strong Middle English word that means scarcity, lack, or shortfall. As in: Currently, we have a dearth of sex and gender research needed to improve and expand the whole big fat pie of better orthopaedic science and healthcare. Compare to its equally punchy antonym, surfeit. Someday!

E - Equality $\neq$ Equity: What's the difference, anyway? Equality means having the same access, status, rights, and opportunities. Equity means fair and impartial treatment, but does not mean equal. An intern may be treated equitably, but does not have equal rights as to, say, a fellow.

F - Female: The sex of the species that can bear offspring or produce eggs, with (usually) XX chromosomes as its defining biologic characteristic. Preferably, female is used as an adjective rather than a noun, such as denoting the sex of the species as female Homo sapiens or in a research study, a female subject. This brings to mind the preferred designation of "subject with diabetes" as opposed to "diabetic" as a stand-alone, dehumanizing noun [6].

G - Gender: Although often considered a polite term for matters related to differences between the sexes, in a scientific context, gender relates to societal and cultural differences between the male and female sex, rather than biologic differences [1]. Therefore, gender is not a synonym for "sex" in the scientific context at all.

H - Hands-on: STEM programs like the Perry Initiative [6] and orthopaedic surgery interest groups in medical schools deliver hands-on, early learning experiences that provide an opportunity to a specialty which, for many, is their first exposure. This is true for underrepresented minorities and especially true for women.

I - Inequality: Inequality pertains to a difference in size, degree, and circumstance. Compare to equality; oft-used in terms of access to status, rights, and opportunities. STEM programs and early exposure to orthopaedic surgery in medical schools provide opportunities to add ballast and balance to a profession still looking a lot like the days before Title IX.

J - Journal: This written record known as Clinical Orthopaedics and Related Research ${ }^{\mathbb{R}}$ is dedicated to its commitment in improving sex and gender reporting in musculoskeletal science.

K - Kinematics $\neq$ kinetics: Kinematics is the study of motion; in orthopaedics, especially the positions of joints in space. Kinetics is the study of applied forces or loading. Both focus on motion, movement, and momentum, which are fundamental to all aspects of orthopaedic surgery. Abnormal load and joint laxity may contribute to osteoarthritis development, and some believe this is why women are predisposed to thumb carpometacarpal (CMC) arthritis. Recent evidence, however, suggests little difference exists in patterns of CMC load and movement between male and female human subjects [2].

L - Landmark: A turning point, important change. Landmark events include: A charter of liberty and political rights for men (Magna Carta in 1215); a declaration of social, civil, and religious condition and rights for woman (Seneca Falls Convention in 1848); the passage of the US women's right to vote $\left(19^{\text {th }}\right.$ Amendment in 1920); the first US woman certified by the American Board of Orthopaedic Surgery [8] (Ruth Jackson in 1937); a ban of sex discrimination in educational institutions (Title IX in 1972).

M - Male: The male sex carries the $\mathrm{XY}$ chromosome complement (usually) of the species. Men represent adult male Homo sapiens, whose gender role sometimes include hunter, as opposed to gatherer.

N - Naysayers: Naysayers say it cannot be done; favorite word: "No." Compare to go-getters like Marie Curie, and Jacqueline Perry.

O - Opportunity: A set of circumstances that makes it possible to do something. See Access, Landmark, Title IX.

P - Progenitor: Often used to describe pluripotential cell lines. Sex of the cell and relationship to progenitor cells requires further investigation. 


\section{Gendered Innovations in Orthopaedic Science}

Q - Quota: A set limit on people or things. The feminine form of Latin quotos, "How many?" Opponents believe Title IX imparts quotas and hurts men's athletic teams. This legislation and its legal interpretations to date do not dictate quotas. Since Title IX has been introduced, men's athletic teams and men's participation in athletics has significantly increased [5].

$\mathbf{R}$ - Research: Investigation in pursuit of new answers and better solutions.

S - Sex: One of two major categories of living organisms, classified by their contributions to reproductive function.

T - Title IX: A landmark amendment to the 1964 Civil Rights Act, which specifically prohibited discrimination in education programs supported by the federal government $[3,5,11]$.

U - Unconscious bias: Ingrained beliefs on how we perceive others and ourselves. Often has a negative connotation. Preconceived notions and assumptions may impair judgment and influence outcomes, especially as it relates to professional and doctorpatient relationships.

V - Vicissitude: A sharp turn of events or fortune, often unpleasant. Waking up with crippling osteoarthritis: Unable to open a jar, button a shirt, or get out of a chair. Losing one's healthcare insurance. Osteoarthritis affects women more than men, for reasons that require more research.
W - Women: Your sister, mother, daughter; perhaps yourself - now presented with many more opportunities than, say, the time of the Seneca Falls Convention.

X - X-chromosome: Fundamental segment of genetic material (gamete) required for both male and female sex determination. $\mathrm{XX}=$ female, $\mathrm{XY}=$ male of the species. Chromosomal aberrations can include XXX, XXY, and many others, which confound strict definition of sex of the species and may present with unusual musculoskeletal conditions.

Y - Y-chromosome: Fundamental segment of genetic material for male sex. See X-chromosome.

Z - Zygote: A cell created from two fused gametes that beget a fertilized egg and life as we know it. Often the result of fraternizing with the opposite sex - enemy or otherwise!

\section{References}

1. Gendered innovations: In science, health \& medicine, engineering, and environment: Available at: http://genderedinnovations.stanford.edu. Accessed August 30, 2014.

2. Halilaj E, Moore DC, Laidlaw DH, Got CJ, Weiss AP, Ladd AL, Crisco JJ. The morphology of the thumb carpometacarpal joint does not differ between men and women, but changes with aging and early osteoarthritis. $J$ Biomech. 2014;47:2709-2714.
3. Ladd AL. Gendered innovations in orthopaedic science: Title IX education: Book learnin' and bone mendin'. Clin Orthop Relat Res. 2014;472:2586-2589.

4. Ladd AL. Let's talk about sex, baby: Gendered innovations in orthopaedic science. Clin Orthop Relat Res. 2014;472:793-795.

5. Ladd AL. The sports bra, the ACL, and Title IX - the game in play. Clin Orthop Relat Res. 2014;472:1681-1684.

6. Leopold SS, Beadling L, Gebhardt MC, Gioe TJ, Potter BK, Rimnac CM, Wongworawat MD. Editorial: Words hurt-avoiding dehumanizing language in orthopaedic research and practice. Clin Orthop Relat Res. 2014;472:2561-2563.

7. Pregnant crash test dummies: Rethinking standards and reference models. Available at: http://genderedinnovations.stanford.edu/case-studies/crash. html\#tabs-1. Accessed August 30, 2014.

8. Ruth Jackson Orthopaedic Society. Ruth Jackson. Available at: http:// rjos.org/about-us/ruth-jackson/. Accessed September 29, 2014.

9. The bottom line: Connecting corporate performance and gender diversity. Available at: http://catalyst.org/knowledge/bottom-line-corporate-performance-and-womens-representation-boards. Accessed August 30, 2014.

10. The Perry outreach program. Available at: http://perryinitiative.org. Accessed August 30, 2014.

11. United States Department of Labor. Title IX, education amendments of 1972. Available at: http://www.dol. gov/oasam/regs/statutes/titleix.htm. Accessed March 19, 2014. 